Yoshitaka Fujii MD, Hiroyoshi Tanaka MD, Hidenori Toyooka MD*

\title{
Reduction of postoperative nausea and vomiting with granisetron
}

The antiemetic effects of granisetron, a selective 5-hydroxytryptamine type 3 receptor antagonist. on postoperative nausea and vomiting were studied and compared with placebo and metoclopramide in 60 patients undergoing general anaesthesia for major gynaecological surgery. The patients received a single $i v$ dose of either granisetron ( $\mathrm{mg}, n=20$ ) metoclopramide ( $10 \mathrm{mg}, n=20$ ), or placebo (saline, $n=20$ ) immediately after recovery from anaesthesia. The effects were assessed during the first three and the next $21 \mathrm{hr}$ afier recovery from anaesthesia by means of a nausea and vomiting score; $0=$ no emetic symptoms, $1=$ nausea, $2=$ vomiting. The mean seores during $0-3$ hr were 0.8, 0.1 and 0.1 afier administration of placebo, metoclopramide and granisetron, respectively; the corresponding scores during 3-24 hr were 0.6, 0.5 and 0.1. The scores of the metoclopramide and the granisetron groups were different from the placebo group in the first three hours $(P<0,05)$. Although there were no differences in the scares during $0-3$ $h r$ between the metoclopramide and the granisetron groups, there were differences during 3-24 hr $(P<0.05)$. II is concluded that granisetron is superior to metoclopramide in the long-term prevention of postoperative nausea and yomiting after anaesthesia.

Les propriétés antiémétiques postopératoires du granisetron, un aniagoniste sélectif des récepteurs de type 3 de la 5 hydroxytryptamine, sont etudièes et comparées à un placébo et à la métoclopramide chez 60 patientes soumises à une anesthésie générale pour des opérations gynécologiques majeures. Les

\section{Key words}

COMPLICATIONS: nausea, vomiting;

VOMITING: antiemetics; granisetron, metoclopramide, incidence, nausea.

From the Department of Anaesthesiology, Toride Kyodo General Hospital, 5901-1, Terada, Toride City, Ibaraki 302, Japan and *Department of Anaesthesiology and Critical Care Medicine, Tokyo Medical and Dental University School of Medicine, 1-5-45, Yushima, Bunkyo-ku, Tokyo 113, Japan. Address correspondence to: Dr. Y. Fujii. Accepted for publication 28 th November, 1993. patients reçoivent une seule dose iv de granisetron $(3 \mathrm{mg}, n$ (20), de métoclopramide (10 $\mathrm{mg}, \mathrm{n}=20$ ) ou de placébo (soluté physiologique, $n=20$ ) immédiatement) après le réveil. Les effets sont évalués pendant les trois premières et les 21 heures suivantes au moyen d'une échelle de nausées et vomissements; $0=$ aucum symprôme, $1=$ nausées, $2=$ vomissements. Les scores moyens de $0-3 \mathrm{~h}$ sont respectivement de $0,8,0,1$ et 0,1 après l'administration du placébo, de la métoclopramide et du granisetron; les scores correspondants de 3-24 h sont de 0,6, 0,5 et 0,1 . Les scores des groupes métoclopramide et granisetron sont différents du groupe placébo pendant les trois premières heures $(P<0,05)$. On ná pas trowvé de différences entre les scores de la période de 0-3 h entre les groupes métoclopramide et granisetron, mais il y àvait des différences entre ces groupes pendant la période de 3-24h $(P<0,05)$. On conclut que le granisetron est suppérieur à la métoclopramide pour la prévention à long terme de la nausée et des vomissements postopératoires.

Postoperative nausea and vomiting occur frequently in women undergoing general anaesthesia for major gynaecological surgery. ${ }^{1}$ Antiemetic drugs, including antihistamines (e.g., hydroxyzine), butyrophenones (e.g., droperidol) and dopamine receptor antagonists (e.g., metoclopramide), are used commonly to prevent these postoperative problems. ${ }^{2,3}$ However, these antiemetics have undesirable side effects which include excessive sedation, hypotension, dry mouth, dysphoria, hallucinations and extrapyramidal symptoms.

Recently, it has been reported that ondansetron, a selective 5-hydroxytryptamine type $3\left(5-\mathrm{HT}_{3}\right)$ receptor antagonist, has antiemetic effects for preventing postoperative nausea and vomiting. ${ }^{4}$ Another $5-\mathrm{HT}_{3}$ receptor antagonist, granisetron (Kytril ${ }^{\circledR}$ ), has a more potent and longer acting activity against cisplatin-induced emesis than ondansetron. ${ }^{5}$ However, its antiemetic effect in postoperative patients has not been reported. The present study was performed to clarify the postoperative antiemetic effects of granisetron in a randomized, doubleblind comparison with placebo and metoclopramide in patients undergoing major gynaecological surgery. 
TABLE I Demographic and anaesthetic data

\begin{tabular}{lccc}
\hline Group & $\begin{array}{c}\text { Placebo } \\
(n=20)\end{array}$ & $\begin{array}{c}\text { Metoclopramide } \\
(n=20)\end{array}$ & $\begin{array}{l}\text { Granisetron } \\
(n=20)\end{array}$ \\
\hline Age (yr) & $47.3 \pm 9.3$ & $46.7 \pm 10.1$ & $45.5 \pm 8.6$ \\
Height (cm) & $152.8 \pm 5.9$ & $152.4 \pm 4.7$ & $153.5 \pm 5.1$ \\
Weight (kg) & $\$ 4.1 \pm 7.6$ & $55.2 \pm 9.1$ & $52.5 \pm 6.0$ \\
Duration of operation (min) & $81 \pm 34$ & $82 \pm 29$ & $81 \pm 39$ \\
Duration of anaesthesia (min) & $108 \pm 38$ & $108 \pm 34$ & $104 \pm 40$ \\
Types of operation performod & & & 16 \\
- Abdominal hysterectomy & 15 & 15 & 0 \\
- Vaginal hysterectomy & 0 & 1 & 3 \\
- Salpingo-cophorectomy & 3 & 3 & 1 \\
- Others & 2 & 1 & \\
\hline
\end{tabular}

All values are expressed as mean $\pm \mathrm{SD}$.

\section{Methods}

Sixty female patients undergoing general anaesthesia for major gynaecological surgery were included in the study after approval by the ethical committee of the Toride Kyodo General Hospital, and informed consent was obtained from each patient. The patients ranged in age from 28 to $67 \mathrm{yr}$ and were ASA physical status I or II. All patients were free of cardiovascular, pulmonary, renal, hepatic or neurological diseases. In addition, they had never received any antiemetic drug within $24 \mathrm{hr}$ of surgery.

As premedication, all patients were given atropine sulphate $0.5 \mathrm{mg}$ im $30 \mathrm{~min}$ before the induction of anaesthesia. In the operating room, patients were placed in the lateral decubitus position. A 17-gauge Tuohy needle was inserted at the $\mathrm{L}_{2-3}$ or $\mathrm{L}_{3-4}$ interspace using the loss of resistance technique and an 18-gauge epidural catheter was placed cephalad (approximately $5 \mathrm{~cm}$ ) through the needle. After catheter placement, the patients were placed in the supine position. Anaesthesia was induced with thiopentone $4-5 \mathrm{mg} \cdot \mathrm{kg}^{-1}$ iv and succinylcholine $1.5-2$ $\mathrm{mg} \cdot \mathrm{kg}^{-1} i v$ was used to facilitate tracheal intubation after precurarization with pancuronium $0.02 \mathrm{mg} \cdot \mathrm{kg}^{-1} i \mathrm{i}$. After tracheal intubation, anaesthesia was maintained with nitrous oxide $4 \mathrm{~L} \cdot \min ^{-1}$, oxygen $2 \mathrm{~L} \cdot \min ^{-1}$ and isoflurane $0.5-2.0 \%$. Ventilation was controlled mechanically and was adjusted to maintain PETCO ${ }_{2}$ between 35 and $40 \mathrm{mmHg}$ with an anaesthetic/respiratory gas analyzer (Capnomac Ultima, Datex, Finland). After the circulation had stabilized, $10-15 \mathrm{ml}$ lidocaine $1.5 \%$ were injected through the epidural catheter. Neuromuscular blocking agents were used as required. At the end of surgery, atropine sulphate $0.02 \mathrm{mg} \cdot \mathrm{kg}^{-1} \dot{N}$ and neostigmine $0.04 \mathrm{mg} \cdot \mathrm{kg}^{-1}$ iv were administered for reversal of muscle relaxation and the tracheas were extubated. Rectal temperature was monitored and maintained at 37 $\pm 1^{\circ} \mathrm{C}$. The patients received, in a randomized, double- blind manner, a single in dose of granisetron ( $3 \mathrm{mg}$ ), metoclopramide (10 mg), or placebo (saline) immediately after emergence from anaesthesia. No additional antiemetics were administered for $24 \mathrm{hr}$ after anaesthesia.

Postoperatively, patients were interviewed by other anaesthetists who did not know which antiemetics the patients had received, and episodes of emesis experienced by each patient were assessed during the first three (0-3) and the next 21 (3-24) hr after recovery from anaesthesia by means of a nausea and vomiting score; $0=$ no emetic symptoms, 1 = nausea, 2 = vomiting. In addition, details of any side effect experienced by the patients were recorded throughout the study.

Demographic and anaesthetic data were analyzed with one-way analysis of variance (ANOVA) and Student's t test. The scores of postoperative nausea and vomiting were compared with $\chi^{2}$ test followed by Kruskal-Wallis test. A $P$ value $<0.05$ was considered significant. All values were expressed as mean \pm standard deviation (SD).

\section{Results}

Demographic and anaesthetic data in the three groups were not different (Table I).

During $0-3 \mathrm{hr}$ after recovery from anaesthesia, the scores of postoperative nausea and vomiting in patients who received metoclopramide $(0.1)$ and granisetron $(0.1)$ were lower than those of placebo $(0.8)(P<0.05)$ (Table II). During 3-24 hr after anaesthesia, the scores showed differences between the placebo $(0.6)$ and the granisetron (0.1) groups $(P<0.05)$. However, no differences in the scores were observed between placebo and metoclopramide $(0.5)$ groups. There were differences between the metoclopramide and the granisetron groups $(P<0.05)$ (Table III).

No side effects were reported by any patient after administration of the antiemetics. 
TABLE II Postoperative nausea and vomiting scores during $0-3 \mathrm{hr}$ after anaesthesia

\begin{tabular}{lllll}
\hline & \multicolumn{4}{l}{ No. of patients } \\
\cline { 3 - 5 } Group & Mean score & Score 0 & Score 1 & Score 2 \\
\hline $\begin{array}{l}\text { Placebo } \\
(n=20)\end{array}$ & 0.8 & 11 & 3 & 6 \\
$\begin{array}{l}\text { Metoclopramide } \\
(n=20)\end{array}$ & 0.1 & 18 & 2 & 0 \\
$\begin{array}{l}\text { Granisetron } \\
(n=20)\end{array}$ & 0.1 & 19 & 0 & 1 \\
\hline
\end{tabular}

Scoring scale: $0=$ no emetic symptoms, $1=$ nausea, $2=$ vomiting.

TABLE III Postoperative nausea and vomiting scores during 3-24 hr after anaesthesia

\begin{tabular}{lllll}
\hline & & \multicolumn{3}{l}{ No. of patients } \\
\cline { 3 - 5 } Group & Mean score & Score 0 & Score I & Score 2 \\
\hline $\begin{array}{l}\text { Placebo } \\
(n=20)\end{array}$ & 0.6 & 12 & 5 & 3 \\
$\begin{array}{l}\text { Metoclopramide } \\
(n=20)\end{array}$ & 0.5 & 12 & 6 & 2 \\
$\begin{array}{l}\text { Granisetron } \\
(n=20)\end{array}$ & 0.1 & 19 & 1 & 0 \\
\hline
\end{tabular}

Scoring scale: $0=$ no emetic symptoms, $\mathrm{l}=$ nausea, 2 = vomiting

\section{Discussion}

The main findings of the present study were that during 0-3 hr after recovery from anaesthesia, the nausea and vomiting scores showed no differences between the metoclopramide and the granisetron groups, but there were differences between the two groups during $3+24 \mathrm{hr}(P$ $<0.05$ ).

Many factors may influence the incidence of nausea and vomiting after surgery performed under general anaesthesia. In the present study, the treatment groups were similar in terms of patient characteristics, surgical procedure, type of anaesthesia and analgesics used postoperatively. Therefore, the differences in the scores among the groups can be attributed to the difference in the agents tested.

Granisetron is a selective antagonist of serotonin at the $5-\mathrm{HT}_{3}$ receptor with antiemetic effects against cisplatin-induced nausea and vomiting. ${ }^{6}$ Our results indicated that granisetron has a potent antiemetic effect on postoperative nausea and vomiting. Although the precise mechanism of granisetron in the prevention of postoperative emesis remains unclear, it is possible that granisetron may act at the area postrema and the nucleus tractus solitarius which contains a number of $5-\mathrm{HT}_{3}$ receptors. $^{7}$ In addition, granisetron may also play the peripheral action of $5-\mathrm{HT}_{3}$ receptors in the small intestine.
It is known that effective doses of granisetron are between 40 and $80 \mu \mathrm{g} \cdot \mathrm{kg}^{-1}$ for the treatment of cancer therapy-induced nausea and vomiting. ${ }^{8}$ In the present study, therefore, granisetron was administered in a dosage of $3 \mathrm{mg}$ (approximately $60 \mu \mathrm{g} \cdot \mathrm{kg}^{-1}$ ) $i v$.

The results of the present study, with administration of placebo and metoclopramide, were in agreement with our previous report. ${ }^{9}$ Thus, during $0-3 \mathrm{hr}$ after recovery from anaesthesia, the postoperative nausea and vomiting scores in the metoclopramide group were lower than those of the placebo group. However, there were no differences in the scores between the two groups during 3-24 hr after anaesthesia.

The present study also demonstrated that the scores of the granisetron group were similar to those of the metoclopramide group within the first three hours after recovery from anaesthesia, and that the scores of the granisetron group were lower than those of the metoclopramide group during the next $21 \mathrm{hr}$ after anaesthesia. This suggests that granisetron has a potent antiemetic effect that lasts up to $24 \mathrm{hr}$.

No adverse effects were observed in either the metoclopramide or the granisetron groups in the present study. This was not in accordance with Scheller's report which described toxic neurological reactions in patients received metoclopramide. ${ }^{10}$ This difference may have been caused by the relatively small number of patients in the present study.

In conclusion, the present study suggests that administration of granisetron is superior to that of metoclopramide in the long-term prevention of postoperative emesis after anaesthesia.

\section{References}

1 Madej T, Simpson $K$. Comparison of the use of domperidone, droperidol and metoclopramide in the prevention of nausea and vomiting following gynaecological surgery in day cases. Br J Anaesth 1986: 58: 879-83.

2 McKenzie R, Wadhwa $R$, Uy $N$, et al. Antiemetic effectiveness of intramuscular hydroxyzine compared with intramuscular droperidol. Anesth Analg 1981; 60: 783-8.

3 Kartila $K$, Kauste A, Auvinen J. Comparison of domperidone, dropericol, and metoclopramide in the prevention and treatment of nausea and vomiting after balanced general anaesthesia. Anesth Analg 1979; 58: 396-400.

4 Bodner $M$, White $P$. Antiemetic efficacy of ondansetron after outpatient laparoscopy. Anesth Analg 1991; 73: 250-4.

5 Andrews PLR, Bhandari P, Dovey PT, Bingham S, Marr $H E$, Blower $P R$. Are all 5- $\mathrm{HT}_{3}$ receptor antagonists the same? Eur J Cancer 1992; 28: S2-S6.

6 Carmichael J, Cantwell BMJ, Edwards CM, et al. A pharmacokinetic study of granisetron (BRL 4369A), a selective 
5- $\mathrm{HT}_{3}$ receptor antagonist: correlation with anti-emetic tesponse. Cancer Chemother Pharmacol 1989; 24: 45-9.

7 Kilpatrick GJ, Jones BJ, Tyers $M B$. The distribution of specific binding of the 5- $\mathrm{HT}_{3}$ receptor ligand

$\left[{ }^{3} \mathrm{H}\right] \mathrm{GR} 65630$ in rat brain using quantitative autoradiography. Neurosci Lett 1988; 94: 156-60.

8 Furue $H$, Oota $K$, Taguchi $T$, Nitani $H$. Clinical evaluation of granisetron against nausea and vomiting induced by anticuncer drugs (1) - optimal dose-finding study. Journal of Clinical and Therapeutic Medicine 1990; 6: 49-61.

9 Fujii $Y$, Tanaka $H$. Postoperative anti-emetic effects of low dose droperidol. Masui 1993; 42: 694-7.

10 Scheller $M S$, Sears $K L$. Postoperative neurologic dysfunction associated with preoperative administration of metoclopramide. Anesth Analg 1987; 66: 274-6. 